\title{
Multiport minimally invasive skull base surgery: how many ports are too many?
}

Yaron A. Moshel

Thomas Jefferson University

Theodore H. Schwartz

Weill Cornell Medical Center

Follow this and additional works at: https://jdc.jefferson.edu/neurosurgeryfp

Part of the Medical Neurobiology Commons, and the Neurology Commons Let us know how access to this document benefits you

\section{Recommended Citation}

Moshel, Yaron A. and Schwartz, Theodore H., "Multiport minimally invasive skull base surgery: how many ports are too many?" (2010). Department of Neurosurgery Faculty Papers. Paper 10. https://jdc.jefferson.edu/neurosurgeryfp/10

This Article is brought to you for free and open access by the Jefferson Digital Commons. The Jefferson Digital Commons is a service of Thomas Jefferson University's Center for Teaching and Learning (CTL). The Commons is a showcase for Jefferson books and journals, peer-reviewed scholarly publications, unique historical collections from the University archives, and teaching tools. The Jefferson Digital Commons allows researchers and interested readers anywhere in the world to learn about and keep up to date with Jefferson scholarship. This article has been accepted for inclusion in Department of Neurosurgery Faculty Papers by an authorized administrator of the Jefferson Digital Commons. For more information, please contact: JeffersonDigitalCommons@jefferson.edu. 


\section{As submitted:}

World Neurosurgery

\section{Later published as:}

\section{Multiport minimally invasive skull base surgery: How many ports are too many?}

\section{Volume 73, Issue 6, June 2010, Pages 632-633 \\ DOI: 10.1016/j.wneu.2010.05.015}

Yaron A. Moshel, Theodore H. Schwartz

New York, NY

Surgical access to the ventral skull base has evolved considerably over the past several years with the introduction of minimally invasive endoscopic and endoscopeassisted approaches. The accompanying manuscript by Ciporen et al. demonstrates an addition to this growing body of literature in their description of the feasibility of multiportal endoscopic approaches to the skull base, particularly the precaruncular transorbital approach, in a series of cadaver dissections. Similar to laparoscopic abdominal surgery, which utilizes multiple small ports to improve visualization and manipulation, they envision a modular combination of approaches that allows an endoscope to be placed in one port and surgery performed through additional ports. One could imagine such an approach lending itself to the use of the DaVinci robot, which also requires multiple ports of access. However, the utility of the endonasal and transcranial 
approaches alone or in combination have already been demonstrated (1-9). The novelty of this paper lies in the additional evaluation of the less well-described precaruncular transorbital approach. This approach has been best described by the group in Seattle who also authored the current article $(10,11)$.

While combining approaches is certainly both logical and precedented when a single approach is inadequate to address a particular pathology, it is unclear from this report if the precaruncular transorbital approach will stand on equal footing with the endonasal and supraorbital approaches that have integrated themselves into standard neurosurgical practice. The authors propose that the precaruncular approach is advantageous because it provides a direct route to the sella, suprasellar region and clivus, improved access to the lateral sella and cavernous sinus and provides another port so that the endoscope is not sharing space with the instruments. However, the endonasal approach is also a direct route to the sella, albeit slightly longer and its extensions such as the transpterygoid (12) or transethmoid approach (13) provide access to lateral structures. Such extensions were not investigated in the current study. In addition, the working space within the sphenoid sinus is larger than the virtual space between the orbit and the lamina papyracea, which may be more important than the absolute distance from the target. Finally, the well-described and clinically useful supraorbital approach is already available to provide an additional port if one is required to supplement the endonasal approach and it is not clear how the precaruncular approach adds further value.

The precaruncular approach requires retraction of the orbit and removal of a significant proportion of the lamina papyracea. These two drawbacks are not fully developed by the authors. The fact that the precaruncular approach requires retraction of 
the orbital contents and precisely how the globe will respond to this manipulation over the course of a long skull base procedure is not clear. The previously published cases performed by the authors utilizing this approach were mainly for repair of CSF leaks and access to the medial rectus or orbital wall after trauma $(10,11)$. Whether the approach will be equally suited for the purposes described in this cadaver study is ambiguous. Additionally, removal of the lamina papyracea may have two functional consequences. First, the globe may recede causing enophthalmos, which can be cosmetically disfiguring thereby undermining the entire purpose of minimal access surgery. Second, the medial rectus muscle can get caught on the remaining shelf of bone causing diplopia, as has been described after endonasal decompression of the orbit for Graves' disease (14-16). If the instruments as well as the endoscope are being passed though the precaruncular approach, a significant amount of bone will need to be removed, compared with the creation of a limited corridor just for the endoscope. Perhaps reconstruction of the lamina papyracea will be required. Likewise, mechanisms for dural closure and avoidance of CSF leak though the precaruncular approach are not well-established.

The notion of multiport endoscopic surgery introduces a degree of flexibility into surgical thinking that eliminates what can sometimes be a dogmatic thought process behind the decision to approach a tumor transcranially versus endonasally. Instead, a surgeon can choose the most strategic set of approaches for a particular pathology. We have used the multiport concept in several prior applications. The combination of endonasal endoscopic surgery with intraventricular endoscopic surgery is useful for removing giant sellar-suprasellar tumors that extend high into the lateral ventricles (1). We have also staged the endonasal and intraventricular endoscopic approaches in the 
management of multicompartmental craniopharyngiomas. The combination of the supraorbital craniotomy with the endonasal approach has been useful to remove esthesioneuroblastomas, in place of a craniofacial and cranionasal approach, if the tumor extends unilaterally over the orbit or into the ethmoid sinuses. Likewise, olfactory groove meningiomas that extend inferiorly into the ethmoid sinuses and laterally over the orbit can benefit from this combined approach. Finally, we have removed large multicompartmental petrous apex and medial sphenoid wing meningiomas through staged transcranial-endonasal approaches. Whether the addition of the precaruncular approach to these already established multiport surgeries will be of value remains to be determined.

In spite of these potential drawbacks, the authors of this article have an extensive history of pioneering skull base approaches and thus we must give them the benefit of the doubt. Clearly the next step is a to perform this approach in a series of patients to determine practical feasibility. These results will be critical to fully evaluate the utility of this new approach and its role in multiport minimally invasive endoscopic surgery and to identify the situations where a single port will not be adequate.

\section{References}

1. Greenfield JP, Leng LZ, Chaudhry U, Brown S, Anand VK, Souweidane MM, Schwartz TH. Combined simultaneous endoscopic transsphenoidal and endoscopic transventricular resection of a giant pituitary macroadenoma. Minim Invasive Neurosurg. Oct 2008;51(5):306-309.

2. Schwartz TH, Fraser JF, Brown S, Tabaee A, Kacker A, Anand VK. Endoscopic cranial base surgery: classification of operative approaches. Neurosurgery. May 2008;62(5):991-1002; discussion 1002-1005.

3. Alleyne CH, Jr., Barrow DL, Oyesiku NM. Combined transsphenoidal and pterional craniotomy approach to giant pituitary tumors. Surg Neurol. Jun 2002;57(6):380-390; discussion 390. 
4. D'Ambrosio AL, Syed ON, Grobelny BT, Freda PU, Wardlaw S, Bruce JN. Simultaneous above and below approach to giant pituitary adenomas: surgical strategies and long-term follow-up. Pituitary. 2009;12(3):217-225.

5. Loyo M, Kleriga E, Mateos H, de Leo R, Delgado A. Combined supra-infrasellar approach for large pituitary tumors. Neurosurgery. Apr 1984;14(4):485-488.

6. Menovsky T, Grotenhuis JA, de Vries J, Bartels RH. Endoscope-assisted supraorbital craniotomy for lesions of the interpeduncular fossa. Neurosurgery. Jan 1999;44(1):106-110; discussion 110-102.

7. Noguchi A, Balasingam V, McMenomey SO, Delashaw JB, Jr. Supraorbital craniotomy for parasellar lesions. Technical note. J Neurosurg. May 2005;102(5):951-955.

8. Raza SM, Garzon-Muvdi T, Boaehene K, Olivi A, Gallia G, Lim M, Subramanian $\mathrm{P}$, Quinones-Hinojosa A. The supraorbital craniotomy for access to the skull base and intraaxial lesions: a technique in evolution. Minim Invasive Neurosurg. Feb;53(1):1-8.

9. Reisch R, Perneczky A, Filippi R. Surgical technique of the supraorbital key-hole craniotomy. Surg Neurol. Mar 2003;59(3):223-227.

10. Moe KS. The precaruncular approach to the medial orbit. Arch Facial Plast Surg. Nov-Dec 2003;5(6):483-487.

11. Moe KS, Kao CH. Precaruncular medial canthopexy. Arch Facial Plast Surg. JulAug 2005;7(4):244-250.

12. Hofstetter CP, Singh A, Anand VK, Kacker A, Schwartz TH. The endoscopic, endonasal, transmaxillary transpterygoid approach to the pterygopalatine fossa, infratemporal fossa, petrous apex, and the Meckel cave. J Neurosurg. Nov 20 2009.

13. Greenfield J, Kacker A, Brown S, Tabaee A, Anand V, Schwartz T. Endoscopic, endonasal, transethmoidal, transcribriform, transfovea ethmoidalis approach to the anterior skull base and anterior cranial fossa. Neurosurgery. (in press).

14. Chiarelli AG, De Min V, Saetti R, Fusetti S, Al Barbir H. Surgical management of thyroid orbitopathy. J Plast Reconstr Aesthet Surg. Feb;63(2):240-246.

15. Leong SC, White PS. Outcomes following surgical decompression for dysthyroid orbitopathy (Graves' disease). Curr Opin Otolaryngol Head Neck Surg. Feb;18(1):37-43.

16. Vaseghi M, Tarin TT, Levin PS, Terris DJ. Minimally invasive orbital decompression for Graves' ophthalmopathy. Ann Otol Rhinol Laryngol. Jan 2003;112(1):57-62. 